\title{
Hydrochemical Factors and Correlation Analysis in Groundwater Quality in Yenagoa, Bayelsa State, Nigeria
}

\author{
H.O. Nwankwoala ${ }^{1}$, A.N. Amadi ${ }^{2, *}$, E. Oborie ${ }^{3}$, F.A Ushie ${ }^{4}$ \\ ${ }^{1}$ Department of Geology, University of Port Harcourt, Nigeria \\ ${ }^{2}$ Department of Geology, Federal University of Technology, Minna, Nigeria \\ ${ }^{3}$ Department of Geology and Physics, Niger Delta University, Bayelsa State, Nigeria \\ ${ }^{4}$ Department of Geosciences, Akwa Ibom State University, Ikot Akpaden, Nigeria \\ *Corresponding author: geoama76@gmail.com
}

Received June 30, 2014; Revised July 07, 2014; Accepted August 07, 2014

\begin{abstract}
This study involves the determination of the hydrochemistry of groundwater and its suitability for drinking, domestic and other purposes in the area. Results show that Hardness range between 2.53mg/l - 5.06mg/l with a mean value of $3.69 \mathrm{mg} / \mathrm{l}$, indicating that the water from the area is soft. Electrical conductivity (EC) level ranges from $6.23 \mu \mathrm{S} / \mathrm{cm}-13.74 \mu \mathrm{S} / \mathrm{cm}$ with a mean of $9.80 \mu \mathrm{S} / \mathrm{cm}$. $\mathrm{pH}$ range from $6.50-6.86$ with a mean value of 6.66 , indicating slightly acidic water. TDS range from $5.77 \mathrm{mg} / \mathrm{l}-18.30 \mathrm{mg} / \mathrm{l}$ with a mean value of $11.4 .1 \mathrm{mg} / \mathrm{l}$. Temp ranges from $26^{\circ} \mathrm{C}-27^{\circ} \mathrm{C}$ with a mean value of $26.6^{\circ} \mathrm{C}$. Calcium $\left(\mathrm{Ca}^{2+}\right)$ ranges from $2.26 \mathrm{mg} / \mathrm{l}-4.08 \mathrm{mg} / \mathrm{l}$ with a mean of $2.97 \mathrm{mg} /$ l. Iron $\left(\mathrm{Fe}^{2+}\right)$ range from $0.01 \mathrm{mg} / \mathrm{l}-0.98 \mathrm{mg} / \mathrm{l}$ with a mean of $0.32 \mathrm{mg} /$. Magnesium $\left(\mathrm{Mg}^{2+}\right)$ ranges from $0.52 \mathrm{mg} / \mathrm{l}-1.23 \mathrm{mg} / \mathrm{l}$ with a mean of $0.89 \mathrm{mg} / \mathrm{l}$. Sodium $\left(\mathrm{Na}^{+}\right)$range from $0.37 \mathrm{mg} / \mathrm{l}-2.38 \mathrm{mg} / \mathrm{l}$ with a mean of $1.18 \mathrm{mg} / \mathrm{l}$. Potassium $\mathrm{K}^{+}$range from $0.20 \mathrm{mg} / \mathrm{l}-1.62 \mathrm{mg} / \mathrm{l}$ with a mean of $0.91 \mathrm{mg} /$. Chloride $\left(\mathrm{Cl}^{-}\right)$range from $6.25 \mathrm{mg} / \mathrm{l}-12.67 \mathrm{mg} / \mathrm{l}$ with a mean of $9.06 \mathrm{mg} / \mathrm{l}$. Bicarbonate $\left(\mathrm{HCO}_{3}^{-}\right)$on the other hand range from $10.18 \mathrm{mg} / \mathrm{l}$ $20.48 \mathrm{mg} / \mathrm{l}$ with a mean of $13.98 \mathrm{mg} / \mathrm{l}$ while Sulphate $\left(\mathrm{SO}_{4}{ }^{2-}\right)$ range from $0.44 \mathrm{mg} / \mathrm{l}-2.56 \mathrm{mg} / \mathrm{l}$ with a mean of $\left.1.46 \mathrm{mg} / \mathrm{l}\right)$ respectively. Results from the area show that the water is not highly mineralized. The values of the parameters are within permissible limits when compared with WHO 2006 and NSDWQ 2007 with exception of Iron which shows high concentration. Also the low chloride concentration indicates no salt water encroachment. The dominant cation and anion in the groundwater from the study area are $\mathrm{Ca}^{2+}$ and $\mathrm{HCO}_{3}{ }^{-}$respectively. The ions owe their origin to rainfall and dissolution of minerals from the Benin Formation where the wells tap from. It is recommended that seasonal variation of groundwater chemistry studies be carried out regularly to detect any future degradation in the area and the results would be used for decision and policy making.
\end{abstract}

Keywords: hydrogeology, hydrochemistry, geostatistics, groundwater quality, Yenagoa, Nigeria

Cite This Article: H.O. Nwankwoala, A.N. Amadi, E. Oborie, and F.A Ushie, "Hydrochemical Factors and Correlation Analysis in Groundwater Quality in Yenagoa, Bayelsa State, Nigeria.” Applied Ecology and Environmental Sciences, vol. 2, no. 4 (2014): 100-105. doi: 10.12691/aees-2-4-3.

\section{Introduction}

Hydrogeochemical processes in groundwater are largely controlled by the physical and chemical interactions that occur between the groundwater water and the aquifer materials. Hydrogeochemical processes are responsible for the seasonal, temporal and spatial variations of groundwater chemistry and consequently the quality (Rajmohan and Elango 2004; Bolaji and Tse, 2009; Nwankwoala, 2013).

The majority of the populace in Yenagoa use groundwater mainly for drinking and other domestic purposes. Since the available surface water is generally polluted with solid and other wastes generated from oil activities, but the groundwater undergoes a natural purification process. However, as a result of industrial activities springing up in the area and other anthropogenic activities of man i.e. poor sanitary conditions of the teeming population and agriculture etc, the quality of groundwater in the study area is under threat as a result of contamination. Thus, it becomes imperative to undertake a groundwater chemistry survey in the area to ascertain its quality for drinking, domestic and other purposes.

Acra and Udom (2006) assessed the quality status of groundwater in parts of Bayelsa State and observed that the groundwater is less mineralized with ${ }_{\mathrm{p}} \mathrm{H}$ values showing slightly acidic groundwater and high iron content. Nwankwoala, et al., (2011) investigated heavy metals in groundwater systems of parts of Bayelsa and reported on high concentrations in majority of the areas. Amadi et al., (1989), assessed groundwater quality in parts of the Niger Delta and concluded that the geochemical characteristics of the groundwater are thought to be closely related to the peculiar geologic and hydrologic conditions that prevail in the Niger Delta region. Groundwater provides a reasonably constant supply that is not likely to dry up under natural conditions, as surface sources may do. In Bayelsa State which is rapidly expanding and 
industrialization going on, coupled with the nearness of the area to the sea, possibilities abound that groundwater quality may be affected. Groundwater quality is normally characterized by different physico-chemical characteristics and these parameters change widely due to the type of pollution, groundwater extraction (Amadi, 2009; Agbalagba et al., 2011). Hence a continuous monitoring of groundwater becomes imperative and mandatory in order to minimize the groundwater pollution and have control on the pollution causing agents. It is against this background that the present study is geared towards determining the suitability of the ground water of the area, through various physicochemical parameters. Therefore, periodic examination to ascertain the quality of the groundwater becomes very necessary. This study is carried out to assess the quality of water for drinking and domestic purposes as well as serve as guide to proper management of groundwater resources in the area.

\section{Geology/Hydrogeology of the Study Area}

The study area lies between latitudes $4^{\circ} 55^{\prime}$ and $5^{\circ} 05^{\prime} \mathrm{N}$ and longitudes $6^{\circ} 15^{\prime}$ and $6^{\circ} 20^{\prime} \mathrm{E}$ (Figure 1). The area is situated in the Central Niger Delta Sedimentary basin of Southern Nigeria. Access to the area is the Mbiama Yenagoa road. There are other networks of roads linking the different parts of the area and its environs. The area is bounded on the north by Mbiama town in Ahoada West Local Government Area of Rivers State and on the South by Ikoli Creek. It is bounded on the West by Epie Creek and on the East by Kolo Creek.

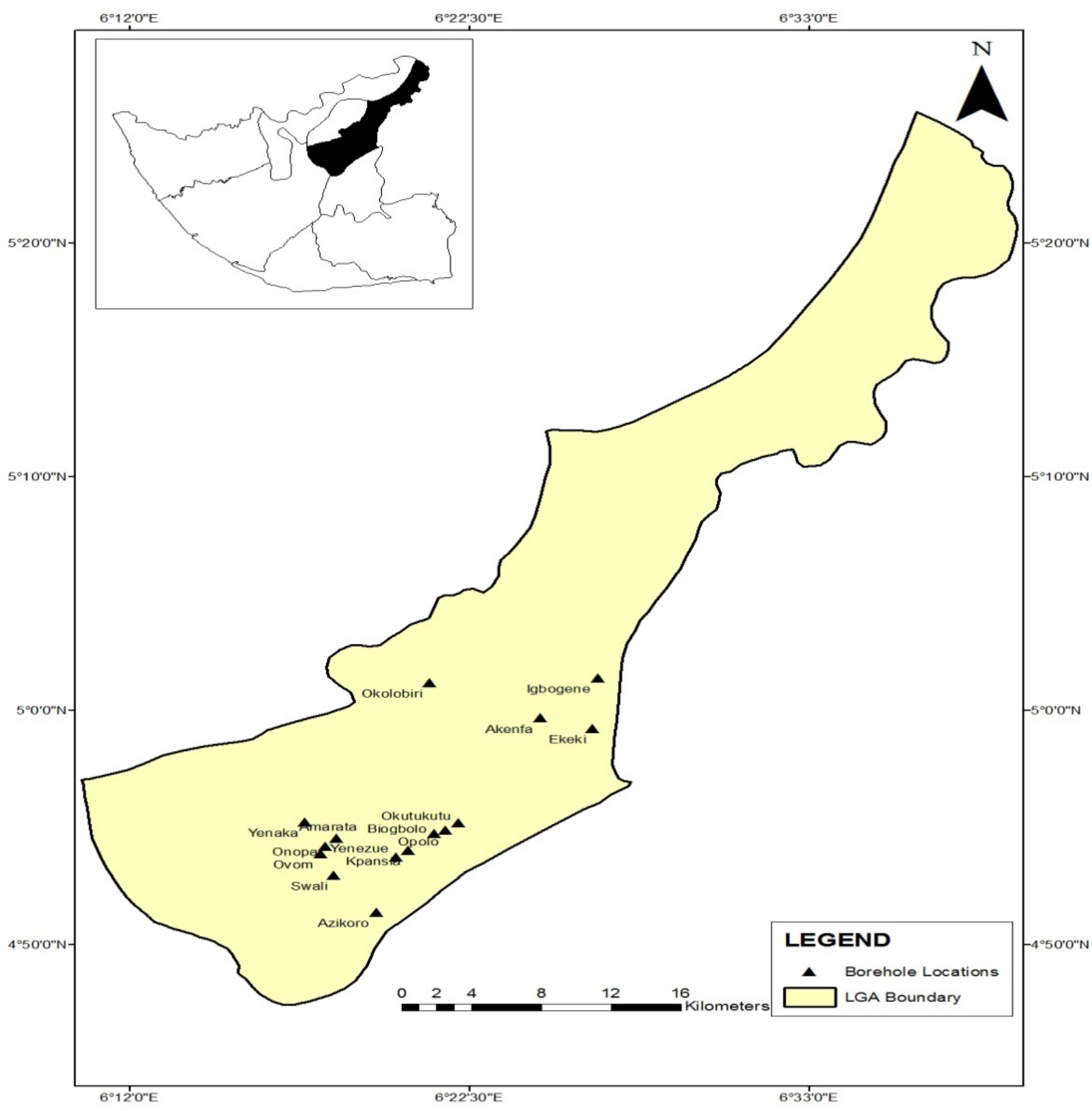

Figure 1. Map of Yenagoa showing sampling locations

Yenagoa, the capital city of Bayelsa State, Nigeria lies in the coastal Niger Delta sedimentary basin. It is endowed with the sedimentary rocks characteristic of the Niger Delta. The detailed geology of the area has been 
described by Allen (1965), Short and Stauble (1967). Lithostratigraphically, the rocks are divided into the oldest Akata Formation (Paleoceone), the Agbada Formation (Eocene) and the youngest Benin Formation (Miocene to Recent). The wells and boreholes tap water from the overlaying Benin Formation (Coastal plain sands). This formation comprises of lacustrine and fluvial deposits whose thicknesses are variable but basically exceeds 1970meters (Asseez, 1989). The Benin Formation has lithologies consisting of sands, silts, gravel and clayey intercalations (Amajor, 1986, 1989, 1991).

The hydrogeology of the study area has been described by several researchers such as; Etu- Efeotor, (1981) Amadi, et al., 1989), Etu-Efeotor and Akpokodje (1990), Edet (1993), and Udom et al., (1998). The Benin Formation is the water bearing zone of the area. It is overlain by Quaternary deposits (40-150m) thick, and generally consists of rapidly alternating sequences of sands and silty clay which later become increasingly prominent seawards (Etu-Efeotor \& Akpokodje, 1990). Generally multi-aquifer systems have been identified in the Delta based on strata logs (Etu-Efeotor, 1981). The first aquifer is mostly unconfined, while the rest are confined. The averages depths of boreholes in Yenagoa are between 20 and 50 metres (Acra \& Udom, 2006). Deep boreholes in the area tap water from depths up to about $200 \mathrm{~m}$ or more. In terms of water quality, Acra \& Udom (2006) have noted that groundwater in most parts of Yenagoa is high in iron content. The static water level in the area ranges from $0-1 \mathrm{~m}$ during the rainy season and $1-3 m$ during the dry season. Rainfall is the major source of recharge for aquifers in the area.

\section{Materials and Methods}

Table 1. Physico-Chemical Parameters of groundwater in Yenagoa

\begin{tabular}{|c|c|c|c|c|c|c|c|c|c|c|c|c|c|c|}
\hline & Location & $\mathrm{T}^{\mathrm{O}} \mathrm{C}$ & ${ }_{\mathrm{p}} \mathrm{H}$ & $\mathrm{EC}(\mu \mathrm{s} / \mathrm{cm})$ & Hardness & TDS & $\mathrm{Ca}^{2+}$ & $\mathrm{Na}^{2+}$ & $\mathrm{Mg}^{2+}$ & $\mathrm{K}^{+}$ & $\mathrm{Fe}^{2+}$ & $\mathrm{HCO}_{3}{ }^{-}$ & $\mathrm{Cl}^{-}$ & $\mathrm{SO}_{4}^{2-}$ \\
\hline & & & & & \multicolumn{10}{|c|}{ Mg/l } \\
\hline 1 & Onopa & 27 & 6.45 & 9.07 & 3.24 & 17.00 & 2.59 & 1.81 & 0.52 & 1.62 & 0.23 & 12.20 & 10.20 & 0.91 \\
\hline 2 & Amarata & 27 & 6.40 & 13.51 & 5.06 & 15.18 & 2.77 & 0.93 & 1.23 & 0.20 & 0.01 & 11.07 & 6.25 & 2.54 \\
\hline 3 & Ovom & 27 & 6.52 & 12.60 & 2.68 & 11.17 & 3.24 & 2.38 & 1.05 & 0.98 & 0.98 & 20.48 & 7.04 & 1.62 \\
\hline 4 & Kpansia & 27 & 6.48 & 6.01 & 4.03 & 12.65 & 4.08 & 0.37 & 0.73 & 0.78 & 0.17 & 12.58 & 12.63 & 0.91 \\
\hline 5 & Opolo & 26 & 6.52 & 12.22 & 2.60 & 9.66 & 2.77 & 0.63 & 0.60 & 0.72 & 0.20 & 15.28 & 8.17 & 1.63 \\
\hline 6 & Biogbolo & 27 & 6.70 & 10.00 & 2.53 & 10.20 & 3.60 & 1.11 & 1.19 & 1.23 & 0.36 & 11.07 & 7.62 & 2.07 \\
\hline 7 & Swali & 26 & 6.54 & 11.66 & 3.52 & 9.22 & 2.68 & 0.93 & 0.98 & 1.24 & 0.32 & 15.24 & 10.20 & 1.03 \\
\hline 8 & Igbogene & 26 & 6.74 & 9.10 & 3.70 & 6.20 & 2.65 & 1.72 & 0.93 & 0.99 & 0.20 & 17.20 & 9.23 & 1.05 \\
\hline 9 & Yenizue & 26 & 6.28 & 7.28 & 4.64 & 5.72 & 4.06 & 1.07 & 0.67 & 0.65 & 0.43 & 13.21 & 9.19 & 2.07 \\
\hline 10 & Yenaka & 27 & 6.68 & 6.50 & 3.75 & 14.04 & 2.68 & 1.08 & 1.20 & 0.68 & 0.44 & 10.18 & 7.07 & 1.24 \\
\hline 11 & Ekeki & 27 & 6.40 & 8.10 & 4.56 & 9.08 & 2.65 & 1.23 & 0.77 & 0.78 & 0.09 & 16.07 & 9.24 & 1.07 \\
\hline 12 & Okolobiri & 27 & 6.58 & 9.12 & 3.73 & 6.22 & 2.68 & 1.68 & 0.94 & 1.00 & 0.21 & 17.21 & 10.17 & 1.07 \\
\hline 13 & Akenfa & 26 & 6.49 & 7.51 & 4.59 & 18.25 & 2.65 & 0.67 & 0.72 & 1.08 & 0.24 & 12.22 & 9.07 & 1.75 \\
\hline 14 & Okutukutu & 27 & 6.48 & 12.20 & 3.01 & 10.21 & 3.21 & 1.23 & 0.86 & 0.73 & 0.80 & 11.23 & 7.20 & 0.44 \\
\hline \multirow[t]{8}{*}{15} & Asikoro & 27 & 6.43 & 8.92 & 3.71 & 15.27 & 2.26 & 0.90 & 1.07 & 0.91 & 0.91 & 14.60 & 12.67 & 2.56 \\
\hline & Min & 26 & 6.23 & 6.01 & 2.53 & 5.72 & 2.26 & 0.37 & 0.52 & 0.20 & 0.01 & 10.18 & 6.25 & 0.44 \\
\hline & Max & 27 & 6.74 & 13.51 & 4.64 & 17.00 & 4.08 & 2.38 & 1.23 & 1.62 & 0.98 & 20.48 & 12.67 & 2.07 \\
\hline & Mean & 26.6 & 6.51 & 9.58 & 3.69 & 11.34 & 2.97 & 1.18 & 0.89 & 0.91 & 0.32 & 14.10 & 9.06 & 1.46 \\
\hline & Range & 1 & 0.46 & 7.50 & 2.11 & 11.28 & 1.82 & 2.01 & 0.71 & 1.42 & 0.97 & 10.30 & 6.42 & 1.63 \\
\hline & Standard deviation & 0.24 & 0.03 & 5.20 & 0.58 & 18.65 & 0.28 & 0.26 & 0.05 & 0.10 & 0.06 & 7.94 & 3.46 & 0.37 \\
\hline & WHO 2006 & & 6.5-8.5 & 500 & 500 & 1000 & 7.5 & 200 & 50 & 200 & 0.3 & - & 250 & 250 \\
\hline & NSDWQ 2007 & & $6.5-8.5$ & - & 150 & 1000 & - & - & 0.20 & - & 0.30 & - & 250 & - \\
\hline
\end{tabular}
after 5 minutes of pumping to ensure the samples were true representative from the aquifer. The samples were stored in sterilized two-litre containers with tightly fitting covers wrapped in a black polyethylene plastic bag and put in a cooler to ensure constant temperature. The containers were first washed with de-ionized water, and then several times with the sample water before collection in order to avoid any contamination.

Parameters like $\mathrm{pH}$ and temperature and electrical conductivity were determined in the field due to their unstable nature. The $\mathrm{pH}$ of the water sample was measured with a pH-meter. The glass tube in the kit was sterilized before been filled to its mark with water sample. The tube was then placed in the space provided in the equipment and a knob adjusted for colour matching, the $\mathrm{pH}$ was then read and recorded. The temperature was read using a mercury thermometer. The electrical conductivity was measured using a Mark electronic switchgear conductivity meter. After sampling, the lids of the containers were immediately replaced to minimize contamination and escape of gases. The samples were then stored in an ice-packed cooler for analysis within 24 hours.

All analyses were carried out at a standardized laboratory using international regulatory methods (APHA, 1995; WHO, 2006,). The evaluation of water quality was in accordance with regulatory standard. The approach ensures that the samples collected were tested in accordance with agreed requirements using competent personnel as well as appropriate equipment and materials.

\section{Results and Discussion}


Also the $\mathrm{pH}$ showed an important variation whereby the water becomes slightly more acidic. The $\mathrm{pH}$ of the groundwater from the study area varied which increased to 6.66, indicating less acidity. TDS of the groundwater from the study area varied with an increase in concentration from a mean value of 11.41. This is as a result of dilution from continuous precipitation in the wet season. Temperature ranges from $26^{\circ} \mathrm{C}$ to $27^{\circ} \mathrm{C}$ with a mean value of $26.6^{\circ} \mathrm{C}$ while Electrical conductivity ranges from 6.23 13.74 with a mean value of 9.83 for wet season.

$\mathrm{pH}$ ranged from 6.50 - 6.86 with a mean value of 6.66 for wet season. The water generally is said to be slightly acidic, characteristic of groundwater's in most parts of the Niger Delta region (Udom et al 1998). The mean $\mathrm{pH}$ values indicate that the water from the region is within the WHO 2006 and NSDWQ 2007 permissible values of 6.58.5 set aside for drinking water (Table 1, Figure 2). Acidity of groundwater in the Niger Delta is partly caused by gas flaring and the presence of organic matter in the soil in the area. The gas flaring from industrial activities releases carbon dioxide and other gases like sulphide which reacts with atmospheric precipitation to form carbonic and sulphuric acids.

Ca ranges from 2.26-4.08mg/l with a mean concentration of $2.97 \mathrm{mg} / \mathrm{l}$. The WHO (2006) standard for domestic water purposes set aside $7.5 \mathrm{mg} / \mathrm{l}$ as the standard for this parameter (Table 1). Thus the water is harmless and safe with regards to this parameter. The presence of calcium in water from the study area is as a result of the dissolution of feldspars and micas in the Benin formation and the adjourning basement complex areas. Na and range from 0.37 - 2.33mg/l, with a mean value of $1.18 \mathrm{mg} / \mathrm{l}$ for wet season. These values are below the WHO (2006) standard of 200mg/l (Table 1, Figure 3). Sodium concentration greater than $50 \mathrm{mg} / \mathrm{l}$ in the presence of suspended matter causes forming and accelerates scale formation and corrosion in boilers (Todd, 1980). Thus water from the study area is free from the tendencies scale formation and corrosion in boilers.

Magnesium ranged from $0.52-1.23 \mathrm{mg} / \mathrm{l}$, with a mean value of $0.89 \mathrm{mg} / \mathrm{l}$ for wet season. The concentration level are low and below the WHO (2006) standard and NSDWQ (2007) of 50mg/l, and 0.20 set aside drinking water (Table 1). Magnesium dissolves from minerals of feldspar and mica etc like calcium. Potassium ranges from $0.20-1.62 \mathrm{mg} / \mathrm{l}$ with a mean value of $0.91 / \mathrm{mg} / \mathrm{l}$ for wet season ((Table 1). The presence of this ion could be probably resulting from the dissolution of feldspar, mica and clay minerals.

Iron with a mean value of $0.32 \mathrm{mg} / \mathrm{l}$ for wet season (Table 1). The WHO (2006) standard and NSDWQ for this parameter is $0.3 \mathrm{mg} / \mathrm{l}$. Thus the water from the area is high in iron content, with some areas exceeding the WHO and NSDWQ limits. Exposure of these water samples to air would lead to the oxidation of $\mathrm{Fe}^{2+}$ ion to $\mathrm{Fe}^{3+}$ ion and precipitate a rust coloured ferric hydroxide which could stain utensils. The Benin Formation which is the water bearing aquifer, from where the groundwater seeps into the wells are ferruginous, and contains iron minerals such as, marcasite, hematite, goethite and limonite. The mobility and subsequent downward infiltration of these minerals through the porous and permeable formation account for the presence of iron in the water from the study area (Amadi et al 2014).

$\mathrm{HCO}_{3}$ ranges from 10.18 - 20.48mg/l, with a mean value of $13.98 \mathrm{mg} / \mathrm{l}$ for wet season (Table 1). The WHO (2006) Standard and NSDWQ (2007) has no limit for this parameter. This parameter is resulting from $\mathrm{CO}_{2}$ in the atmosphere and biota production in the soil. Chloride concentration ranges from $6.25-12.67 \mathrm{mg} / \mathrm{l}$, with a mean value of $9.06 \mathrm{mg} / \mathrm{l}$ (Table 1, Figure 2 and Figure 3). Generally a concentration of $\mathrm{Cl}$ below $20 \mathrm{mg} / \mathrm{l}$ is regarded as low. Thus there is low chloride concentration in the study area and no indication of salt water encroachment into aquifers. A chloride concentration of $40 \mathrm{mg} / \mathrm{l}$ and above in the water is an indicative of salt water encroachment. WHO (2006) standard and NSDWQ (2007) for drinking water stipulates $250 \mathrm{mg} / \mathrm{l}$ as the tolerant value for this parameter (Table 1). In the light of this, water from the study area would be free from chloride related problem. The Sources of chloride in groundwater is rainwater, which is the major source of recharge for the wells.

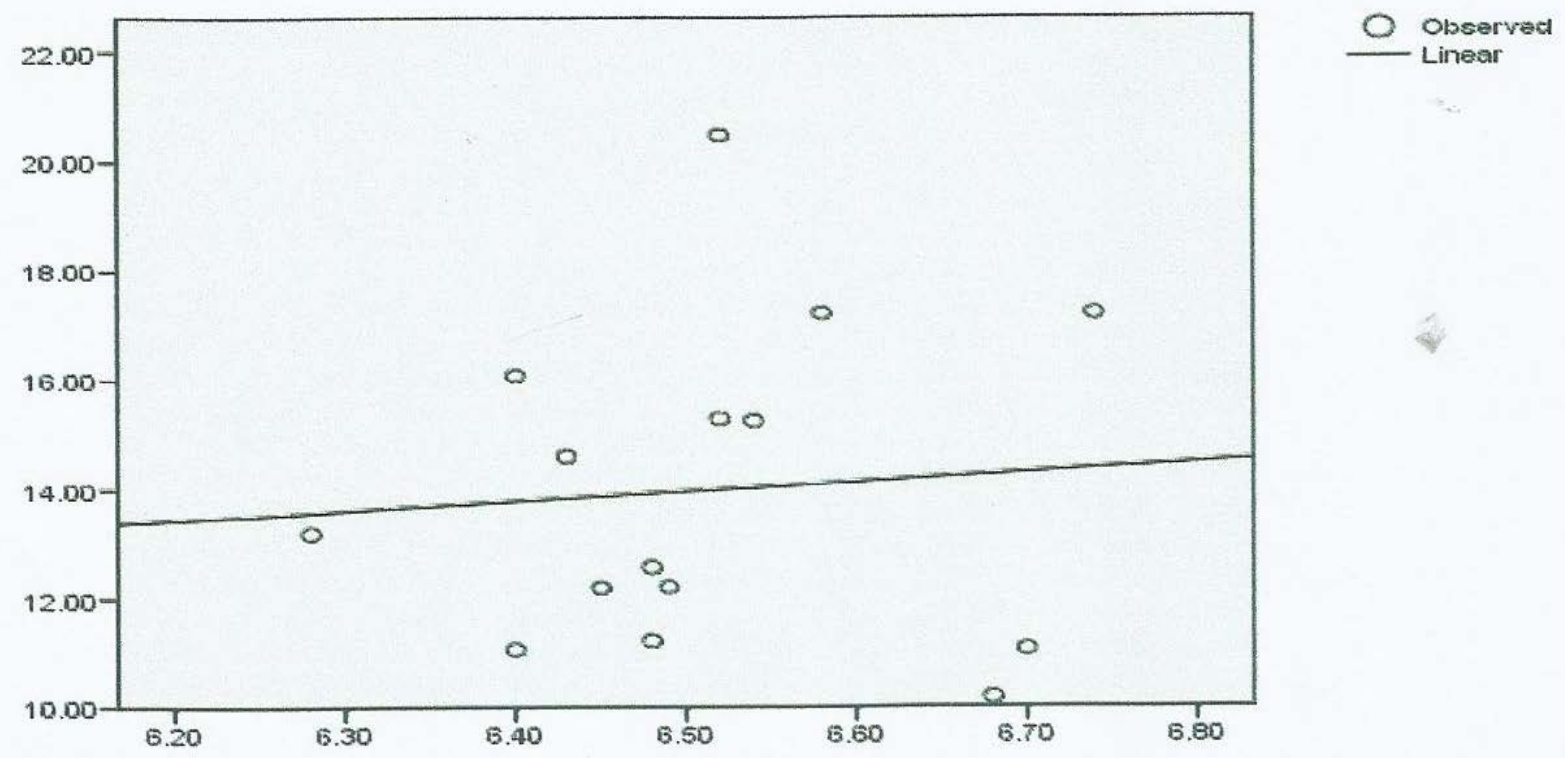

Figure 2. Observed and Linear relationships of $\mathrm{HCO}_{3} / \mathrm{pH}$ 


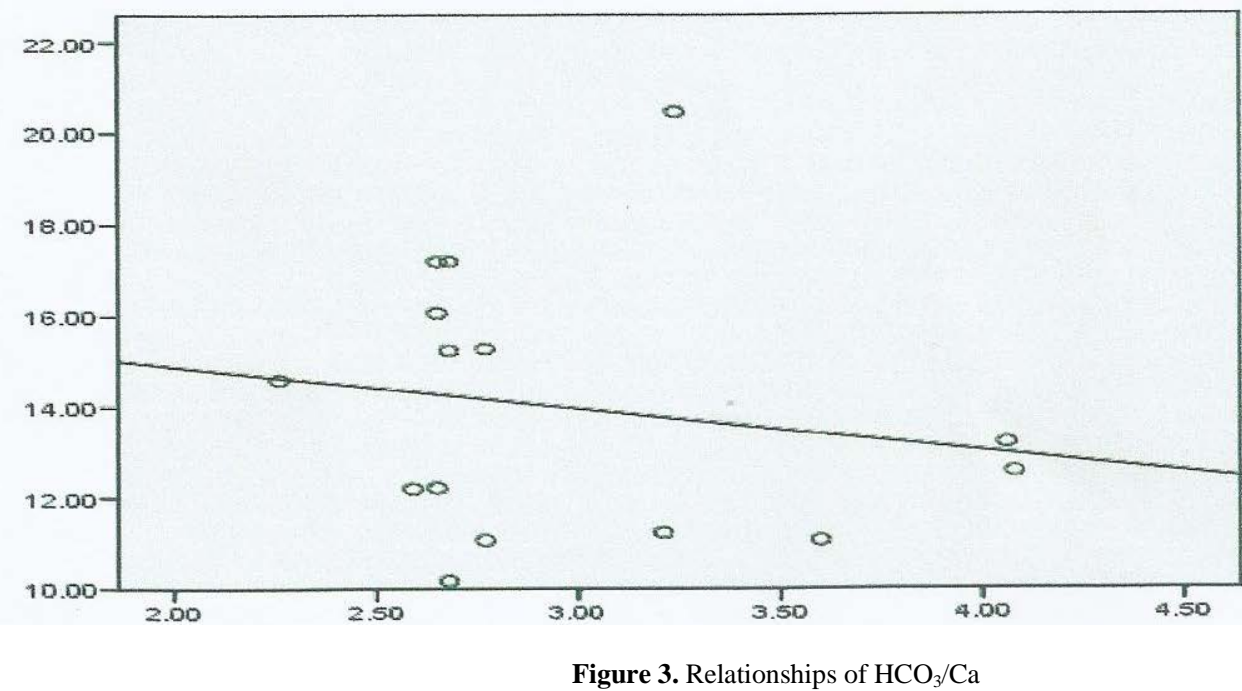

The concentration level of sulphate ranged from 0.44$2.56 \mathrm{mg} / \mathrm{l}$ with a mean value of $1.4 \mathrm{mg} / \mathrm{l}$ (Table 1$)$. The WHO (2006) standard for this parameter is $250 \mathrm{mg} / \mathrm{l}$, respectively. The values obtained were below the WHO limits.

Hardness concentration levels for water samples from the study area ranged from $2.53-5.06 \mathrm{mg} / \mathrm{l}$ with a mean value of $3.69 \mathrm{mg} / \mathrm{l}$ for wet season (Table 1 ). Hardness levels in the range of $0-60 \mathrm{mg} / \mathrm{l}$ is said to be soft. Thus water from the study area is soft and suitable for drinking and other domestic purposes like laundry because soft water lathers easily with soap. The WHO (2006) standard and NSDWQ (2007) for this parameter is $500 \mathrm{mg} / \mathrm{l}$ and $150 \mathrm{mg} / \mathrm{l}$ respectively (Table 1). Thus the hardness concentration values for water from the study area are below the WHO (2006) and NSDWQ (2007) limits and is thus suitable for drinking and domestic purposes.

TDS values ranges from 5.77-18.30 mg/l with a mean value of $11.41 \mathrm{mg} / \mathrm{l}$. The WHO (2006) standard and
NSDWQ (2007) for this parameter for drinking water is $1000 \mathrm{mg} / \mathrm{l}$, thus the water from the study area is safe for drinking and domestic purposes.

\section{Correlation Analysis and Distributions}

Correlation coefficient is a commonly used measure and to assess the relationship between two variables. It is a simple measure to exhibit how well one variable predicts the other. The correlation matrixes for the different variables for the parameters are shown in Table 2. A correlation coefficient (r) of +1 indicates that two variables are perfectly related in a positive linear sense, but $r=-1$ indicates a negative linear correlation. However, no relationship between two variables exists if $r=0$. Thus, two variables having a positive correlation coefficient infer that they have a common source, while negative correlation coefficient indicates different source.

Table 2. Correlation Matrix between major ions

\begin{tabular}{|c|c|c|c|c|c|c|c|c|c|c|c|c|c|}
\hline & Temp & pH & EC & Hardness & TDS & $\mathrm{Ca}^{2+}$ & $\mathrm{Na}^{+}$ & $\mathbf{M g}^{2+}$ & $\mathbf{K}^{+}$ & $\mathrm{Fe}$ & $\mathrm{HCO}_{3}^{-}$ & $\mathrm{Cl}^{-}$ & $\mathrm{SO}_{4}{ }^{2-}$ \\
\hline Temp. $\left({ }^{\circ} \mathrm{C}\right)$ & - & & & & & & & & & & & & \\
\hline $\mathrm{Ph}$ & .489 & - & & & & & & & & & & & \\
\hline $\mathrm{EC}(\mu \mathrm{S} / \mathrm{cm})$ & .486 & .481 & - & & & & & & & & & & \\
\hline Hardness(mg/l) & .346 & .029 & .086 & - & & & & & & & & & \\
\hline TDS (mg/l) & .153 & .290 & .399 & .298 & - & & & & & & & & \\
\hline $\mathrm{Ca}^{2+}(\mathrm{mg} / \mathrm{l})$ & .482 & .250 & .233 & .453 & .126 & - & & & & & & & \\
\hline $\mathrm{Na}^{+}(\mathrm{mg} / \mathrm{l})$ & .184 & .223 & .170 & .112 & .196 & .275 & - & & & & & & \\
\hline $\mathrm{Mg}^{2+}(\mathrm{mg} / \mathrm{l})$ & .080 & .055 & .171 & .470 & .457 & .311 & .343 & - & & & & & \\
\hline $\mathrm{K}^{+}(\mathrm{mg} / \mathrm{l})$ & .406 & .136 & .303 & .036 & .347 & .269 & .096 & .142 & - & & & & \\
\hline $\mathrm{Fe}(\mathrm{mg} / \mathrm{l})$ & .201 & .445 & .243 & .043 & .433 & .434 & .107 & .184 & .382 & - & & & \\
\hline $\mathrm{HCO}_{3}{ }^{-}(\mathrm{mg} / \mathrm{l})$ & .283 & .398 & .203 & .213 & .038 & .267 & .013 & .397 & .276 & .211 & - & & \\
\hline $\mathrm{Cl}^{-}(\mathrm{mg} / \mathrm{l})$ & .442 & .246 & .022 & .315 & .438 & .477 & .162 & .088 & .096 & .460 & .297 & - & \\
\hline $\mathrm{SO}_{4}^{2-}(\mathrm{mg} / \mathrm{l})$ & .432 & .176 & .304 & .185 & .187 & .465 & .221 & .079 & .117 & .361 & .366 & .366 & - \\
\hline
\end{tabular}

\section{Conclusion}

The $\mathrm{pH}$ values of the water show slightly acidic groundwater in the area. The acidity arises from gas flaring in most parts of the Niger Delta as well as the presence of organic matter in the soil. The water should be treated to increase the level of $\mathrm{pH}$ at locations where values are below 6.5. The $\mathrm{pH}$ can be adjusted and effectively achieved through Base Exchange Method with dolomite. Poly vinyl chloride (PVC) materials should be used for borehole construction in the area since acidic waters are aggressive to iron pipes.

Iron values are exceptionally high in some locations. This can be treated by encouraging the iron to precipitate 
when the water is exposed to the air. The ferric hydroxide precipitate is then filtered out to have potable water. Iron bacteria can then be removed from groundwater with water filters. Treatment with alkaline hydrogen peroxide is one surest way of removing dissolved iron from borehole waters. This method, according to (Acra \& Udom, 2006) is preferable than most conventional methods because it is fast, cost effective, environmentally friendly and does not require external coagulant. Generally, the geochemical characteristics of groundwater in the area are believed to be closely related to the peculiar geology and hydrogeologic conditions prevailing in the area. More importantly, hydrogeochemical studies in the area should be carried out regularly to detect any future degradation of the water.

\section{References}

[1] Acra E.J. and Udom G.J. (2006). Hydrochemical characteristics of groundwater in Andoni Local government area, Rivers State. Journal of Research in Physical Sciences, Vol. 2. (1), pp 35-41.

[2] Agbalagba, O.E, Agbalagba O.H., Ononugbo, C.P. and Alao, A.A. (2011). Investigation into physicochemical properties and hydrochemical processes of groundwater from commercial bores holes in Yenegoa, Bayelsa State. African Journal of Environmental Science and Technology Vol. 7, pp 473-483.

[3] Allen, J.R.L., (1965). Aspects of the geology of Nigeria Univ. of Ibadan Press, Nigeria 133p.

[4] Amadi, A. N., Olasehinde, P. I., Nwankwoala, H. O., Dan-Hassan, M. A. and Mamodu Adegbe, (2014). Controlling Factors of Groundwater Chemistry in the Benin Formation of Southern Nigeria. International Journal of Engineering and Science Invention, 3(3), 11-16.

[5] Amadi, A.N., (2009). Physico-chemical and Bacteriological Evaluation of Groundwater in parts of Aba, Abia State, Southeastern Nigeria. International Journal of Applied Biological Research, Vol.1, No. 1, pp 63-71.

[6] Amadi, P.A, Morrison, T. and Ofoegbu, C.O (1989). Hydrogeochemical assessment of groundwater quality in parts of the Niger Delta, Nigeria. Environmental Geology, 14(3), 195-202.

[7] Amajor, L.C. (1986). Geochemical characteristics of groundwater in Port Harcourt and Environs: proceeding of NWASA Symposium, UNILAG, Lagos. Pp 359-376.

[8] Amajor, L.C. (1989). Geological appraisal of groundwater exploitations in the Eastern Niger Delta. In: C.O Ofoegbu, (Ed.), Groundwater and Mineral Resources of Nigeria. Braunschweig/weisbaden. Friedr vieweg and Sohn. Pp. 85-100.
[9] Amajor, L.C. (1991) Aquifers in the Benin Formation (MioceneRecent), Eastern Niger Delta, Nigeria: Lithostratigraphy, Hydraulics, and water Quality. Environmental Geology and Water Sciences 17, No 2: 85-101.

[10] APHA, (1995). American Water Works Association and Water Environment Federation, "Standard Methods for the Examination of Water and Wastewater" (21 $1^{\text {st }}$ Ed). American Public Health Association, Washington DC, USA.

[11] Asseez. L.O. (1989) Review of the Stratigraphy, Sedimentation and Structure of the Niger Delta, in Kogbe C.A. (ed), Geology of Nigeria, Rockview Nigeria Limited; pp. 311-324.

[12] Bolaji T.A. and Tse C.A. (2009). Spatial Variation in groundwater geochemistry and water quality index in Port Harcourt. Scientia Africana, 8(1): 134-155.

[13] Edet, A.E. (1993). Groundwater Quality Assessment in parts of Eastern Niger Delta. Nigeria. Environmental Geology, 22(1), pp 41-46.

[14] Etu-Efeotor J.O. and Akpokodje E.G (1990). Aquifer Systems of the Niger Delta. J. Min. Geol. 26(2): 279-294.

[15] Etu-Efeotor, J.O. (1981). Preliminary Hydrogeochemical investigations of Sub-Surface waters in parts of the Niger Delta Nig. Jour. Min. Geol; 18(1): 103-105.

[16] NSDWQ, (2007). Nigerian Standard for Drinking Water. Nigerian Industrial Standard, NIS: 554, pp13-14.

[17] Nwankwoala, H.O. (2013). Evaluation of Hydrochemical Characteristics of Groundwater in Port Harcourt, Nigeria. Unpublished Ph.D Dissertation, University of Port Harcourt, Nigeria, 294pp

[18] Nwankwoala, H.O; Udom, G.J and Ugwu, S.A. (2011). Some heavy metal investigations in groundwater sources in Yenegoa, Bayelsa State, Nigeria. Journal of Applied Technology in Environmental Sanitation Vol. 1 (2): 163-170.

[19] Rajmohan N and Elango L. (2004). Identification and evolution of hydrogeochemical processes in the groundwater environment in an area of the Palar and Cheyyar River Basins, Southern India. Environmental Geology 46:47-61

[20] Short, K.C. and Stauble, A.J. (1967). Outline Geology of the Niger Delta. AAPG Bull 51; 761-779.

[21] Todd. D.L. (1980). Groundwater Hydrology, John Wiley and Sons, New York pp. 267-315.

[22] Udom, G.J; Esu, E.O; Etu Efeotor, J.O (1998). Hydrochemical Evaluation in parts of Port-Harcourt and Tai-Eleme Local Government Areas of Rivers State. Global Journal of Pure and Applied Sciences 5(5), pp. 545-552.

[23] World Health Organisation (WHO) (2006). International Standards for Drinking Water Quality. $3^{\text {rd }}$ edition, Geneva, pp 346-385. 